DOI: $10.20472 / T E .2015 .3 .2 .001$

\title{
THE CHALLENGING ROLE OF PUBLIC LIBRARIES AS PROVIDERS OF LIFELONG LEARNING OPPORTUNITIES FOR PERSONAL AND SOCIAL SKILLS DEVELOPMENT
}

\author{
AIKATERINI BALAPANIDOU
}

\begin{abstract}
:
Public libraries have been for centuries an integral part of the society offering free places and equal access to resources for leisure and educational purposes. They support both organised and self-conducted learning in all education forms, i.e. formal, non-formal and informal learning for all age groups. However, the global technological developments have changed the demands for easier access to knowledge and the new socio-economic conditions affected informational, educational and training needs throughout life.

Nowadays, they have to find ways to overcome the challenges of the competitive environment, which will enable them to redefine themselves as a vital part of the knowledge society connected to the emerging community needs by becoming more active in lifelong learning. This paper presents an overview of public libraries' role as providers of lifelong learning opportunities. The review is focused on the value-added services provision, including information literacy and other educational programs and activities for personal and social skills development. Additionally, provides some brief information on Greek public libraries and their role in lifelong learning over the last decades.

*The fulfilment of the paper was co-funded through the Hellenic State Scholarships Foundation (IKY) from funds coming from the European Social Fund and the Educational Program "Education and Life Long Learning" (NSRF, 2007 - 2013).

** This paper is a revised version of the paper entitled "Lifelong learning opportunities and challenges for public libraries", presented at the 15th International Academic Conference in Rome, 14-17 April 2015.
\end{abstract}

\section{Keywords:}

public libraries, library services, lifelong learning, lifelong education, skills development, information literacy, social inclusion, Greek libraries

\section{Authors:}

AIKATERINI BALAPANIDOU, UNIVERSITY OF MACEDONIA, Greece, Email: dimkon@arch.auth.gr

\section{Citation:}

AIKATERINI BALAPANIDOU (2015). The challenging role of public libraries as providers of lifelong learning opportunities for personal and social skills development. International journal of Teaching and Education, Vol. III(2), pp. 1-16., 10.20472/TE.2015.3.2.001 


\section{Introduction}

As an integral part of the society public libraries collect, preserve, organize and offer documents contributing to both organized and self-conducted learning in all education levels and forms (formal, non-formal and informal learning), for all age groups without discrimination. Moreover, they provide free places and access to documents not only for educational, but also for leisure purposes. However, maintaining their prominent role in the society is being challenged by the global technological developments. The revolutionary explosion of information resulted in a growing change of the users' preferences to easier access to information via search engines, online retailers and social media.

Another factor that affected informational, educational and training needs is the globalization of the economy. Along with the digital revolution and the multicultural nature of modern societies resulted in social and educational inequalities increase. Therefore, was created the necessity for everyone to update the existing knowledge and acquire new skills and abilities beyond formal learning, throughout their lifetime, in order to meet the demands of the ever changing society. Lifelong learning, as the concept of learning at all stages of life, is expected to motivate individuals and equip them with the necessary and supplementary knowledge, skills and competencies.

Actually, librarians realized that they should adopt new technologies and offer more value-added services; not only access, but also guidance to information retrieval through information literacy programs. In addition, there is a growing consensus that public libraries should revise their traditional role by extending their educational, instructional and consultation services and activities, providing opportunities for personal and social skills development, in order to become key-organizations contributing to the support of both lifelong learning and social cohesion.

Special emphasis has been placed on expanding and strengthening public libraries' role in providing learning opportunities that contribute to the wider social progress, but are public libraries really able to embrace the concept of lifelong learning? This has been the subject of much discussion at an international level. Greece is one of the countries in which public libraries have experienced difficulties in their overall operation. However, many of them have formed cooperative partnerships with other libraries and supportive organizations that have recognized that lifelong learning could assist them overcome the emerging challenges and help them undertake a more active social role within their communities.

The aim of this paper is: (i) to explore the literature and depict a brief overview of the role of public libraries as institutions that offer lifelong learning opportunities connected to the community needs, and (ii) to provide a brief review of Greek public libraries' role in lifelong learning over the last decades.

\section{Methodology}

The resources were retrieved through library repositories and article databases as well as through web-searches. The selected material includes library and information science related journal articles, library associations' related to lifelong learning documents, conference papers, public libraries' bulletins and periodicals; presenting 
guidelines, polices, research, examples, suggestions, and concerns about public libraries' role in lifelong learning worldwide.

The paper consists of four main sections, namely:

- Public libraries and the lifelong learning concept

- Technological challenges and information literacy opportunities

- Socio-economic challenges and learning opportunities

- Greek pubic libraries and their role in lifelong learning.

The first three sections serve as a basis for defining general aspects concerning the relationship between public libraries and lifelong learning, the public libraries' role and mission, and the concept of lifelong learning. They also raise important issues for further discussion on lifelong learning as an emerging theory and practice for public libraries. In this context was examined their challenging role to provide lifelong learning opportunities through information literacy and other educational programs and learning activities that enhance personal and social skills development. The fourth section includes background information, data from surveys related to lifelong learning that have been conducted in Greek public libraries as well as information about more recent advancements.

\section{Public libraries and the lifelong learning concept}

Public libraries have always been collecting, preserving and providing resources and services relating to the history and development of the local community. They offer free places and equal access to resources for educational, informational and personal development both for recreation and leisure (IFLA/UNESCO, 2001). IFLA (International Federation of Library Associations and Institutions), the international body which represents libraries and librarians worldwide, in collaboration with UNESCO (United Nations Educational, Scientific and Cultural Organization), the most important international organization related to educational development, and mainly active in the promotion of the lifelong education, have played a significant role in setting the international library and information services policy framework for public libraries (Lor, 2012).

IFLA and UNESCO in their "Public Library Manifesto" (1994) identified 12 key missions for public libraries, which highlight the importance of public libraries' role in maintaining and expanding access to information, literacy, education, culture and learning opportunities without discrimination, for children and youth as well as for adults.

These key missions are:

1. Creating and strengthening reading habits in children from an early age

2. Supporting both individual and self conducted education as well as formal education at all levels

3. Providing opportunities for personal creative development

4. Stimulating the imagination and creativity of children and young people

5. Promoting awareness of cultural heritage, appreciation of the arts, scientific achievements and innovations

6. Providing access to cultural expressions of all performing arts 
7. Fostering inter-cultural dialogue and favouring cultural diversity

8. Supporting the oral tradition

9. Ensuring access for citizens to all sorts of community information

10. Providing adequate information services to local enterprises, associations and interest groups

11. Facilitating the development of information and computer literacy skills

12. Supporting and participating in literacy activities and programs for all age groups, and initiating such activities if necessary (IFLA/UNESCO, 1994, p.1-2).

Moreover, IFLA and UNESCO (2001) within the guidelines that set for public libraries' services provision also recognized that the public library has an important role in the process of assisting people "acquire new skills at various stages of their life" in the ever-changing increasingly complex society, where learning is regarded as "a lifelong activity" for most people (p.2).

The relationship between public libraries and lifelong learning is commonly identified by several authors using as a reference point a phrase taken from the IFLA/ UNESCO Public Library Manifesto, characterizing public library as "the local gateway to knowledge", providing "a basis for lifelong learning, independent decision-making and cultural development of the individual and social groups" (IFLA/UNESCO, 1994). However, IFLA (2004) emphasized much more clearly the need for strengthening the lifelong learning role of public libraries some years later in the final report on "The Role of Libraries in Lifelong Learning". In this report, which reflects "a more holistic view on education", was given the definition of lifelong learning, as well as the forms of education and training that it contains: "Lifelong learning can be defined as all purposeful learning activity undertaken on an ongoing basis with the aim of improving knowledge, skills and competence. It contains various forms of education and training, formal, non-formal and informal, e.g. the traditional school system from primary to tertiary level, free adult education, informal search and training, individually, in a group setting or within the framework of social movements" (p.2).

The report also referred to the European Commissions' Memorandum, according to which lifelong learning is characterized as "the common umbrella under which all kinds of teaching and learning should be brought together". At this point it would be useful to quote the comprehensive European Commission's definition, according to which lifelong learning includes: "all learning activity undertaken throughout life, with the aim of improving knowledge, skills and competence, within a personal, civic, social and/or employment-related perspective" (European Commission, 2003). In this definition, as Eve, De Groot, \& Scmidt (2007) noted, is stressed the "skills and training aspect of learning", adopting an approach closely related to the benefits of the information age and focusing on "access to information and communication technology (ICT) facilities and training" as well as on "social inclusion" issues (p.394).

\section{Technological challenges and information literacy opportunities}

Their future role and how their profession would be affected by technological changes have been matters of great concern for public librarians for many decades. The public libraries' future was supposed to depend on their "ability to adapt to the necessary 
changes in technology". Additionally, "information complexity" became a great challenge along with the changing community needs (Woods et al, 1989, p.17). As this rapid and continuous explosion of information created a globally growing demand for easier access to information, book collections became outdated, libraries' prominent role in information services and knowledge provision was questioned and their existence was undermined. Many public libraries are still faced with drastic budget cuts and staff reduction; and even some of them were merged and closed. Thus, they began to realize the necessity to prove that are not passive providers of information, just repositories for books or places just for reading. In this evolutionary information society they had to be more competitive, efficient and effective by redefining their role (Rankin \& Brock, 2012; Woods et al, 1989)

Although nowadays access to information through the World Wide Web is much easier, this information overload requires validation and assessment to verify its reliability. Technology, except for the impact that it has on information seeking behaviors, is also altering the need for new skills and competencies development. Snavely (as cited in Lai, 2011) pointed out the fact that even though people claim to have a high degree of confidence in using computers, this does not mean that they also have the adequate information literacy skills.

Public libraries, as a vital part of the community that supports their users, have a crucial role to play in offering guidance and training in how to search, use and rate the quality of information resources. Therefore, while ICT (Information and Communication Technology) expansion and teaching IL (Informational Literacy) became major priorities, new opportunities were opened up for public libraries to provide services that could be considered as a response to technological changes and challenges. From community information centers they can also become learning centers empowering individuals throughout life, which means that additionally to their popular traditional services provision they can create new technology-based and value-added services to fulfill not only the informational users' needs, but also their needs to expand digital citizenship; training in safe and responsible behavior with regard to technology use (Lai, 2011; Eve, De Groot, \& Scmidt, 2007; Kahlert, 2000).

The ALA (American Library Association) (1989) defined as "information literate" the individuals that "have learned how to learn", which means that have the knowledge to "recognize when information is needed" and the ability to find it, evaluate it and use it effectively. Lai (2011) described IL more broadly, in the context of "lifelong learning" as: "the ongoing acquisition of information skills" for: "locating, evaluating, managing and using information effectively from a range of sources for problem solving, decision making and research" (p.82).

IFLA (2006) characterized information competencies as "the first step in achieving educational goals" and "a key factor in lifelong learning, employment, and daily interpersonal communication of any citizen" (p.4), defined them as: "a group of skills to identify information need, as well as retrieving, evaluating, using and reconstructing the knowledge" (p.49) and provided a compilation of guidelines. These guidelines can serve as a framework for planning and implementing an IL program, which can be used by information professionals or be adapted to any library setting. 
In this document IFLA proposed a set of IL standards for the international library community, including three basic components: access, evaluation and use of information. Thus, users in order to become effective learners, they should learn to: (i) access information effectively and efficiently, (ii) evaluate information critically and competently, and (iii) use/apply information accurately and creatively (IFLA, 2006, p.17). Figure 1 illustrates the information competencies.

Figure 1: Information competencies

Access

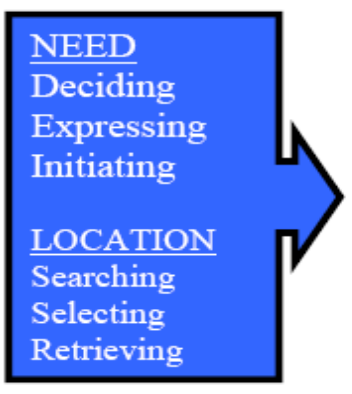

Evaluation

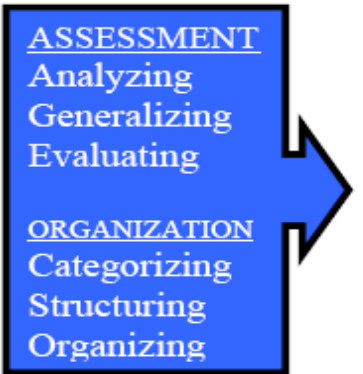

Use

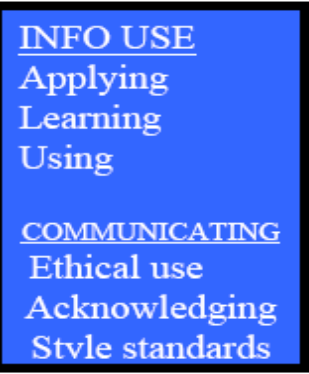

Source: IFLA (2006, p.17)

The design of proper IL courses is a very challenging issue for public libraries and their staff's IL skills are considered as a "significant factor in determining the effectiveness" of users' training (Lai, 2001, p.82). Nowadays, although many public libraries managed to adapt to change and have been transformed to information hubs and learning spaces for sharing professional advice and guidance; technology-based service demands from students, teachers and young people are still emerging rapidly according to the current trends (Giles, 2013; Creelman, 2012).

Creelman (2012) believes that libraries' value in the future will no longer be based on their physical collection, but on the skill levels of their staff to provide services both in the building and on-line. On the other hand, as Nygren (2014) noted, librarians do not always have all the necessary skills "in order to satisfy the digital learning needs of all groups" (p.3). Nevertheless, he suggests that public libraries' can adopt a "connected learning approach" and act as empowering community hubs that promote users' collaboration and participation in IL training through peer-learning. This approach enhances not only learning opportunities, but also social and digital inclusion. Additionally, there are very challenging concerns to provide computer access and instruction to low-income community members and senior citizens.

\section{Socio-economic challenges and learning opportunities}

The economic globalization along with the multicultural nature of modern societies and the explosion of new knowledge created social and educational inequalities for all age groups, especially for adults, and increased instability and insecure employment. Formal education proved to be insufficient to meet the demands of the ever changing society. Therefore, a greater need for investment in continuous training and building of skills and knowledge throughout the life of individuals appeared. The concept of 
lifelong learning was considered to enable people adapt to changes that occurred both in their professional and personal everyday lives (Barros, 2012; Laal \& Salamati, 2012). In this context, public libraries, as an integral part of the society, realised the need to expand training opportunities and schedule learning activities that enhance personal and social skills development as part of a lifelong perspective. Thus, there has been a shift in their current role "from passive, recreational reading and research institutions to active economic development agents" (Manjarrez, Cigna \& Bajaj, 2007, p.4).

Public libraries are an open world for learning and leisure for all age groups, but the majority of their learning activities are traditionally addressed to children and young people. As it was noted previously "creating and strengthening reading habits in children from an early age" as well as "stimulating the imagination and creativity of children" are included in their key missions (IFLA/UNESCO, 1994, p.1). The opportunities offered by public libraries to develop language and literacy skills are considered to be very important and many families rely on them for pre-school learning and love for reading habits (Rankin \& Brock, 2012).

In addition, Manjarrez, Cigna \& Bajaj (2007) stated at this respect that "library early literacy resources and programs are benefiting individuals and the community-atlarge", while investing in early literacy may have "the potential to yield even greater investments" (p.14). Research reveals that early language and literacy development help children's engagement in learning, raise their levels of school readiness, and increase school success (Manjarrez, Cigna \& Bajaj, 2007; Celano \& Neumann, 2001). Bookey (2015) presented examples on this approach of eight public libraries in the United States that encourage early literacy and reinforce family engagement through programs that combine learning and reading with entertainment. These libraries provide to their communities a variety of innovative, interactive and fun-related activities. Parent education and awareness programs along with children activities are becoming very popular and improve public libraries' interaction within their communities.

Another approach currently gaining ground is that of the public library as a place which enables users to update their skills for the workplace. Williamson \& Wallis (1998) some years ago discussed the fact that although "the public library was the originator of lifelong learning", research showed that public libraries as lifelong learning institutions were "staggering". The reason was that government departments, particularly the Employment Service, did not recognize their role as providers of "learning-based opportunities" (p.260). However, the authors noticed that "It's a role must adopt for the 21st century" (p.258). Indeed, as presented in the study "Making cities stronger" many public libraries managed to create partnerships with local workforce agencies in order to facilitate employment and career search within their communities (Manjarrez, Cigna \& Bajaj, 2007).

Motschiling \& Ebner (2014) mentioned that learning opportunities for adults offer benefits that "go beyond the economic and employment-related, extending to social benefits, higher self-esteem, and wellbeing" (p.6). Actually, providing lifelong learning opportunities that raise the general level of citizens' skills, giving priority especially to 
socially disadvantaged groups; people that face difficulties, have learning disabilities or insufficient financial support, and consequently are at most risk of social exclusion, may contribute mutually to the improvement of both economic indicators; such as productivity and employability, and social indicators; such as social inclusion and active citizenship (Motschiling \& Ebner, 2014; Laal \& Salamati, 2012; Fincham \& Ward, 2006). Furthermore, as Fincham \& Ward (2006) noted, when librarians schedule learning activities for adults it is very important to take into account learners' diverse backgrounds, their motivations and interests. The purposes for learning differ and might relate to: "personal development, employment, supporting children [or] working for their community" (p.12).

Rankin \& Brock (2012) ascertain that nowadays there is "a growing interest in the social impact of what libraries can offer and how they can contribute to the social cohesion and development of their communities". They also pointed out that public libraries have been "originally established to produce social change" and they have "a real and valuable role to play in community development" (p.6). MLA (Museums, Libraries and Archives Council) recognized as a challenging and at the same time complex issue the provision of learning opportunities for adults that have underdeveloped literacy, language and numeracy skills. In their "Skills for Life Strategy", which was launched in 2001 in England and Wales, the identified target groups included the following five categories:

- unemployment people and benefit claimants,

- $\quad$ prisoners and people supervised in the community,

- public sector workers,

- low-skilled employed people,

- at risk groups, including: homeless people, adults with learning disabilities, minority ethnic groups, drug or alcohol misusers and mental health service users (Fincham \& Ward, 2006, p.11).

The importance of adult learning "as a tool for social cohesion" that can "narrow gaps between different social groups" and "serve as an important 'equalizer' of well-being and learning opportunities" was highlighted by Motschiling \& Ebner (2014) with a remarkable example: "persons with lower levels of formal education report positive changes in motivation, feel more confident as learners, and more often encouraged others to learn as well" (p.7). Additionally, Rankin \& Brock (2012) referred to public libraries' "measurable and substantial contribution to local economies" which helps bridging social divides. They also stated that public libraries provide services that "support well-being, encourage reading, spread knowledge, contribute to learning and skills" as well as "help to foster identity, community and a sense of place for people of all ages, backgrounds and cultures" (p.7).

\section{Greek pubic libraries and their role in lifelong learning}

Public libraries in Greece used to have a great history as institutions related to education and learning community needs. However, in the contemporary society they have experienced many problems which devalued the importance of their role. Greek public libraries are categorized in three types; depending on their legal status, source 
of funding, administrative responsibilities and their user groups: public, municipalpublic and children's and youth public libraries (Papazoglou \& Semertzaki, 2001; Dewe, 1991; Birk, Karageorgiou \& Shafer, 1988).

More specifically:

(i) Public libraries (also referred as "dimosies") are governed and funded by the Ministry of Education. Their total number today is 46, including the National Library. Nine of them, owning collections with rare and valuable material, have been characterized as "historical" (Public libraries, 2008).

(ii) Municipal-public libraries (also referred as "dimotikes") operate under the responsibility of the local authorities; consisting of the mayor and community leaders. Their total number is approximately 686, including central and many branch libraries (Infolibraries, 2015).

(iii) Children's and youth public libraries are currently supported either by the Ministry of Education or by local authorities, and some of them operate as branch children's libraries. Birk, Karageorgiou \& Shafer (1988) highlighted the importance of this library type as "a start of the lifelong learning concept of library use" (p.10).

Although the necessity for consolidation of all the above three public libraries types has been raised many years ago, this "unification" remains a difficult problem which has not been solved until today (Birk, Karageorgiou \& Shafer, 1988, p.10). Other main problems that they faced were related to "legislation, national planning, finance and local provision" (Dewe, 1991, p.288). Birk, Karageorgiou \& Shafer (1988) also noted that libraries in Greece were used mainly as "study halls" and "were viewed as having a passive rather than an active role", which implied "a serious image crisis" (p.13). Unfortunately, many years later, users' per month statistics still seemed to be very disappointing. Papazoglou \& Semertzaki (2001) reported that the low usage rate was "a well-known trend". Their opinion was based on the fact that there were very few public libraries offering "quality services". Moreover, "overall funding and opening hours were very limited and services very poor (p.164). Therefore, the majority of the population was not much interested in using them.

Taking all the above into account, we can draw a picture of a community in which public libraries' role was seriously undermined. Undoubtedly, there was an urgent need to reverse that negative situation. Papazoglou \& Semertzaki (2001) mentioned that strengthening the role of libraries in Greece was largely the aim of the European Community's action, which through the Community Support Framework provided funding to upgrade "the standards in all areas" such as "buildings, automation, networking, services and organization", in order to create a constant, dynamic and rapid progress in all the Greek libraries (p.166). Concerning public libraries, "their general conditions and the importance of their role in their community were greatly improved" and new standards were set up along with the decision of the Ministry of Education to provide new buildings for four public libraries; in Veria, Pyrgos, Drama and Sparti (p.163).

Before moving forward, it is important to refer to the CSL (Committee for the Support of Libraries), an international organization working in Greece, which was founded in 
2003. The increasing difficulties for libraries worldwide and especially in Greece met the need for the creation of a Committee of Greek and international organizations' representatives. CSL aimed to "contribute to the modernization and development" of Greek libraries efforts to provide "quality services to their users". Additionally, its main missions were: to encourage local and international cooperation in the field of library science, to facilitate the exchange of ideas and experiences, in order to find effective solutions to common problems, and to provide opportunities for professional development and continuing education (Amendolagine, 2009, p.3). According to Amendolagine (2009) the work of the CSL "is becoming increasingly appreciated all over Greece and is reaching out of the boundaries of Greece" (p.15).

It also worths mentioning that in 2004 CSL organized an International Conference under the topic "Libraries and Lifelong Learning", in which lifelong learning was recognized as an important factor that could assist libraries both handle the enormous amount of growing information and meet the emerging challenges. Referring to Greek public libraries' role in lifelong learning, it was concluded that public libraries in Greece were still considered to be places providing activities for "leisure", rather than for "dynamic learning". However, existed the belief that they could become more active in lifelong learning opportunities provision in a way that would "enable every member of the society to achieve his or her potential" (Amendolagine, 2009, p.6).

Balatzaras (2005) ascertained that lifelong learning programs in Greek libraries, was a fairly new service for public libraries, according to the recently established regulation, that should be provided either to groups or to individual users. However, in fact, it seemed more like a mission that many libraries had not managed to accomplish yet. In his research on the role of libraries in lifelong learning assumed that public libraries offered many cultural activities and learning opportunities; as exhibitions, reading discussion groups, seminars and library orientation. On the contrary, the development and provision of lifelong learning programs proved to be an exceptional case only for some libraries, as long as there was not a fully integrated approach implemented in any of the libraries. He also noted that information literacy programs in Greece were provided mainly by academic libraries. Actually, as Sipitanou \& Zarifis (2006) mentioned, those years lifelong learning in Greece was a new concept "both in terms of educational development and of operational program planning" (p.62), while "lifelong learning strategies have been partially incorporated and institutionalized" (p.63).

Another research was conducted some years later by Theodoridou \& Fanara (2011) in 33 Greek public libraries aiming to collect information about lifelong learning programs provision and librarians' views on lifelong learning. Research revealed that almost all the participants (97\%) claimed to be familiar to the concept of lifelong learning; while more than half of them (51.5\%) answered that their libraries provided lifelong learning programs/services. According to the answers the public libraries that took part in the survey provided: collection development oriented to lifelong learning (25.5\%), educational material and alternative education programs (19.6\%), flexible training programs in new technologies (15.7\%), experiential learning programs $(13.7 \%)$, educational activities in a physical and/or a virtual environment (11.8\%), and services 
for specific population groups (such as immigrants and disabled) (11.8\%). There was also one library that supported training programs for academic institutions graduates. In terms of collaboration, many librarians indicated that existed between organizations from the public; as educational centers, schools, municipalities and/or from the private sector; as professors and publishers. With regards to the implementation and provision of lifelong learning programs, only $6.1 \%$ stated that they did not face any problems. Most of the respondents reported lack of financial support (31.5\%), lack of both adequate (19.6\%) and trained professional staff (16.3\%), and only some of them lack of technological equipment (10.9\%) (Theodoridou \& Fanara, 2011).

A most recent research was prompted by the need to investigate the impact of the current socioeconomic crisis to the role and services of the libraries in Greece (and Cyprus). According to Giannakopoulos, Koulouris \& Kokkinos (2014) Greek libraries since 2009 have experienced many problems related to "funding and personnel reduction". Concerning Greek public libraries, the authors reported that, unfortunately, they "were at the bottom of the state's priorities even before the crisis". However, they indicated that "the role of libraries within the crisis environment creates both threats and opportunities" in order to "adapt to the ongoing changes and form a survival development plan within the new reality" (p.412). The most significant finding was the common belief among the participants (94\%) that libraries can play a supportive role for the users that have been affected by the crisis. In addition, recommended that public libraries in order to "enhance their social role" should: provide free Internet access, participate in social media, organize cultural events, and support information literacy programs as well as other formal and informal lifelong learning programs (p.417).

It would be a great omission not to refer to the most active and innovative Greek public library, the Veria Central Public Library. This library emerged as a leader in Greece offering a wide range of innovative services and learning programs based in new technologies. It worths mentioning that for its "creative use of information and technology services" and the wide range of programs that provided, meeting "the economic, educational and cultural needs of more than 180,000 people", in 2010 was awarded with the "Access to Learning Award" and a 1,000,000€ funding from the Bill \& Melinda Gates Foundation (Bentley, 2015).

In 2011, Veria Central Public Library with the exclusive donation from the Stavros Niarchos Foundation, established Future Library; a non-profit organization, which formed a network of public and municipal libraries across Greece, with the aim to reinforce "the significance of libraries as knowledge, creativity, and interaction promoting institutions" (Future Library, 2015). In the Future Library Network currently participate 140 Public and Municipal Libraries and about 7,354 individual members. It is also remarkable the fact that during these years it has renovated 8 children's libraries in Central Macedonia and established 9 Media Labs across the country. Furthermore, it has already hosted over 9,800 events in more than 100 Greek cities (Bentley, 2015). The learning activities, programs and campaigns that has organised were addressed mainly to children. Moreover, has provided training to the staff of the member libraries. Finally, it worths mentioning that the upcoming "Summer Campaign" 
for the promotion of reading and creativity, which is organized by the National Library of Greece in cooperation with the Future Library Network, aims for the fist time to attract not only children but also adults (National Library of Greece, 2015).

\section{Conclusions and recommendations}

To sum up, public libraries since their existence have not only been providing opportunities for information, learning and education, but also had the advantage to offer the basis for lifelong learning, as it was recognized by IFLA and UNESCO. As the global developments transformed the information environment and challenged public libraries' existence, librarians realised that they should upgrade their role by transforming their libraries to innovative and technologically updated learning hubs close to local communities providing guidance and assistance services for meaningful use of the learning material and online resources. In this context, librarians can play a crucial role as facilitators that expand information literacy and digital inclusion.

Furthermore, responding to the changing socio-economic conditions, public libraries can also support social inclusion and enhance self-efficacy for all ages and without discrimination; from early literacy to adult learning for the elderly. Offering learning opportunities should be addressed especially to marginal populations and groups that are at most risk of social exclusion, through educational programs and activities that will encourage their personal and social skills update and development as well as their knowledge and ideas creation.

In Greece, public libraries' role has been devalued, due to serious operation problems, related basically to limited and uncertain funding as well as to inadequate and not appropriately educated staff. However, there is a common sense that they should move forward. The cooperation with supportive organizations, as the CSL, and with other more active libraries, as the Veria Central Public Library, will enable them learn from each other and develop common strategies to strengthen their position in the "information society" as well as enhance their social image and the interaction within their communities.

Public libraries worldwide in order to fulfil their role as providers of critical skills necessary for lifelong learning, it is very important to ensure that all the quality requirements, according to the guidelines that have been suggested by IFLA/UNESCO (2001) and other supportive organizations, for the development of their services are being met. In addition, they do not only need to obtain the appropriate technologies, but they also need to be proactive, participate in lifelong learning projects, have professionally trained staff able to respond to the users' needs and able to create partnerships with other experienced professionals.

Last but not least, it would be useful to mention that librarians should keep in mind the key issues for the success of every service or activity they offer; they have to take into account the literacy, training and learning users' needs, they should assess regularly the learning outcomes, and they should use evaluation methods to measure users' satisfaction for the improvement of the learning opportunities provided and the raising of the standards of living and quality of life within their communities. 


\section{Acknowledgements}

The fulfilment of the paper was co-funded through the Hellenic State Scholarships Foundation (IKY) from funds coming from the European Social Fund and the Educational Program "Education and Life Long Learning" (NSRF, 2007 - 2013).

\section{References}

ALA (1989). Presidential Committee on Information Literacy. Final Report. [Online] Chicago: American Library Association. Available from: http://www.ala.org/acrl/publications/whitepapers/presidential. [Accessed: 10 th March 2015].

AMEDOLAGINE, A. (2009) The Committee for the Support of Libraries: a model of library networking in Greece. In: IFLA WLIC 2009. Libraries create futures: Building on cultural heritage. Milan, Italy, 23-27 August 2009. [Online] Available from: http://conference.ifla.org/past-wlic/2009/162amendolagine-en.pdf. [Accessed: 30th April 2015].

BALATZARAS, M. (2005). Dia viou mathisi kai o rolos ton vivliothikon [Lifelong learning and the role of libraries (in Greek)] Master Thesis. Korfu: Ionian University.

BARROS, R (2012) From lifelong education to lifelong learning: discussion of some effects of today's neoliberal policies. European journal for Research on the Education and Learning of Adults. [Online] SCOPUS 3(2). p.119-134. [Accessed: 30th April 2015].

BENTLEY, S. L. (2015) Reviving the library in Greece: the future is now for the Future Library Network and the INELI-Balkans project. [Online] $3^{\text {rd }}$ April. Available from: www.huffingtonpost.com. [Accessed: 30th April 2015].

BIRK, N., KARAGEORGIOU, D. \& SHAFER, S. L. (1988). Greek public libraries: an assessment. International library review. [Online] Taylor \& Francis 20(1). p.5-17. Available from: http://www.tandfonline.com. [Accessed: 25th April 2015].

BOOKEY, J. L. (2015) 8 awesome ways libraries are making learning fun. The Huffington Post. [Online] $29^{\text {th }}$ April. Available from: www.huffingtonpost.com. [Accessed: 30 ${ }^{\text {th }}$ April 2015].

CELANO, D. \& NEUMANN, S. B. (2001). The role of public libraries in children's literacy development. [Online] Pennsylvania Library Association. Available from: http://www.ifpl. org/Junior/studies/Role\%20of\%20Libraries.pdf. [Accessed: $4^{\text {th }}$ April 2015].

CREELMAN, A. (2012) Public libraries as learning spaces. Scandinavian Library Quarterly. [Online] 45(1). p.16-17. Available from: http://slq.nu/wp-content/uploads/2012/03/SLQ1.2012.pdf. [Accessed: $2^{\text {nd }}$ March 2015].

DEWE, M. (1991) The new central public library for Veria, Greece. International library review. [Online] Taylor \& Francis 23(4). p.287-298. Available from: http://www.tandfonline.com. [Accessed: 25th April 2015].

EUROPEAN COMMISSION (2003) What is Lifelong Learning?. [Online] Available at: http://ec.europa.eu/education/policies/ll//life/what_islll_en.html. [Accessed: 22 ${ }^{\text {nd }}$ February 2015].

EVE, J., DE GROOT, M. \& SCHMIDT, A.-M. (2007) Supporting lifelong learning in public libraries across Europe. Library Review. [Online] Emerald Database 56(5). p.393-406. Available from: http://www.emeraldinsight.com. [Accessed: 22 ${ }^{\text {nd }}$ February 2015].

FINCHAM, G. \& WARD, J. (2006). Inspiring adults: literacy, language and numeracy in the museums, libraries and archives sector. London: National Institute of Adult Continuing Education (NIACE) / Museums, Libraries and Archives Council (MLA).

FUTURE LIBRARY (2015) About Future Library [Online] Available from: http://about.futurelibrary.gr/. [Accessed: 29th April 2015].

GIANNAKOPOULOS, G, KOULOURIS, A. \& KOKKINOS, D. (2014) Libraries in crisis: a glimpse over Greece and Cyprus. Procedia-Social and Behavioral Sciences, [Online] Elsevier 147. p.411-417. Available from: http://www.sciencedirect.com. [Accessed: 28 $8^{\text {th }}$ April 2015].

IFLA (2004) The role of libraries in lifelong learning. Final report of the IFLA project under the section for public libraries. [Online] IFLA. Available from: http://archive.ifla.org/VII/s8/proj/LifelongLearningReport.pdf. [Accessed: 14 ${ }^{\text {th }}$ January 2015]. 
IFLA (2006) Guidelines on information literacy for lifelong learning. [Online] IFLA. Available from: http://www.ifla.org/files/assets/information-literacy/publications/ifla-guidelines-en.pdf. [Accessed: $10^{\text {th }}$ March 2015].

IFLA/UNESCO (1994) IFLA/UNESCO Public library manifesto 1994. [Online] IFLA. Available at: http://www.ifla.org/publications/iflaunesco-public-library-manifesto-1994. [Accessed: $14^{\text {th }}$ January 2015].

IFLA/UNESCO (2001) The public library service: IFLA/UNESCO guidelines for development. München: De Gruyter Saur. [Online] IFLA. Available from: http://www.ifla.org/files/asset s/hq/publications/archive/the-public-library-service/publ97.pdf. [Accessed: 15 th January 2015].

INFOLIBRARIES (2015) Public Libraries Gateway. Available from: http://www.infolibraries.gr. [Accessed: 25 th $A$ pril 2015].

KAHLERT, M. (2000) Lifelong learning: a public library perspective. In: ALIA 2000. Capitalising on knowledge: The Information Profession in the 21 $1^{\text {st }}$ Century. Canberra, Australia, 23-26 October 2000. [Online] ERIC Database. Available from: http://eric.ed.gov. [Accessed: $30^{\text {th }}$ January 2015].

LAAL, M. \& SALAMATI, P. (2012) Lifelong learning; why do we need it?. Procedia-Social and Behavioral Sciences. [Online] Elsevier 31. p.399-403. Available from: http://www.sciencedirect.com. [Accessed: $2^{\text {nd }}$ February 2015].

LAI, H.-J. (2011) Information literacy training in public libraries: a case from Canada. Educational Technology \& Society. [Online] ERIC Database 14 (2). p.81-88. Available from: http://eric.ed.gov. [Accessed: $5^{\text {th }}$ February 2015].

LOR, P. J. (2012) The IFLA-UNESCO partnership 1947-2012. In: IFLA WLIC 2012. Libraries Now! Inspiring, Surprising, Empowering. Helsinki, Finland, 11-17 August 2012. [Online] Available from: http://conference.ifla.org/past-wlic/2012/96-lor-en.pdf [Accessed: 30th January 2015].

MANJARREZ, C. A., CIGNA, J. \& BAJAJ, B. (2007) Making cities stronger: public library contributions to local economic development. [Online] Urban Libraries Council. Available from: http://www.urban.org/publications/1001075.html. [Accessed: $6^{\text {th }}$ February 2015].

MOTSCHILNIG, R. \& EBNER, G. (2014) Engaging new learners in adult education: short guide for policy-makers and adult educators. [Online] Brussels: OED. Available from: http://www.oednetwork.eu. [Accessed: $6^{\text {th }}$ February 2015].

NATIONAL LIBRARY OF GREECE (2015) Kalokairini ekstrateia 2015 [Summer campaign 2015 (in Greek)]. [Online] Available from: http://summer2015.nlg.gr. [Accessed: 30th April 2015].

NYGREN, A. (2014) The public library as a community hub for connected learning. In: IFLA WLIC 2014. Libraries, Citizens, Societies: Confluence for Knowledge. Lyon, France, 16-22 August 2014. [Online] Available from: http://library.ifla.org/1014/1/167-nygren-en.pdf. [Accessed: $30^{\text {th }}$ January 2015].

PAPAZOGLOU, A. \& SEMERTZAKI, E. (2001) Changes and developments in Greek libraries. The Electronic Library. [Online] Emerald Database 19(3). p.158-167. Available from: http://www.emeraldinsight. com. [Accessed: 25 th April 2015].

PUBLIC LIBRARIES (2008) The Greek public libraries portal. [Online] Available from: http://publiclibs.ypepth.gr. [Accessed: $25^{\text {th }}$ April 2015].

RANKIN, C. \& BROCK, A. (2012) Library services for children and young people: an overview of current provision, future trends and challenges. In: Rankin, C. \& Brock A. (eds.) Library Services for children and young people: challenges and opportunities in the digital age. London: Facet. p. 327.

SIPITANOU, A. \& ZARIFIS, G. (2006) Lifelong learning in Greece. In: N. Terzis (ed.) Lifelong learning in the Balkans: education and pedagogy in Balkan countries. Thessaloniki: Kyriakides brothers. p.61-116.

THEODORIDOU, M. \& FANARA, M. (2011) Ereuna gia tin parochi programmaton dia viou mathisis stis Ellinikes dimosies vivliothikes [Survey on the provision of lifelong learning programs in Greek public libraries (in Greek)]. Dissertation. Thessaloniki: Alexander Technological Educational Institution of Thessaloniki. 
WILLIAMSON, M. J. \& WALLIS, M.K. (1998) The role of the public library in lifelong learning: can Cinderella go for the ball?. In: Holford, J., Jarvis, P. \& Griffin, C. (eds.) International perspectives on lifelong learning. London: Routledge. p.256-265.

WOODS, L. B. et al. (1989) Public libraries: focusing on the 1990s. Library Review. [Online] Emerald Database 38(4). p15-24. Available from: http://www.emeraldinsight.com. [Accessed: $25^{\text {th }}$ February 2015]. 